\title{
Distribution of the Planktonic Shrimp Lucifer (Thompson, 1829) (Decapoda, Sergestoidea) off the Amazon
}

\author{
Melo, NFAC. ${ }^{a *}$, Neumann-Leitão, S. ${ }^{b}$ Gusmão, LMO. ${ }^{b}$, Martins-Neto, FE. ${ }^{a}$ and Palheta, GDA. ${ }^{a}$ \\ aPrograma de Pós-graduação em Aquicultura e Recursos Aquáticos Tropicais, Instituto Socioambiental e dos Recursos \\ Hídricos - ISARH, Universidade Federal Rural da Amazônia - UFRA, Avenida Presidente Tancredo Neves, \\ 2501, CEP 66077-530, Belém, PA, Brazil

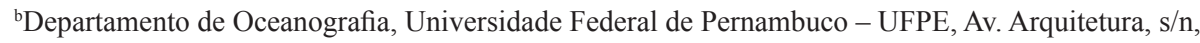 \\ Cidade Universitária, CEP 50670-901, Recife, PE, Brazil \\ *e-mail: nuno.melo@ufra.edu.br
}

Received: September 18, 2012 - Accepted: May 27, 2013 - Distributed: November 30, 2014

(With 7 figures)

\begin{abstract}
Lucifer faxoni (BORRADAILE, 1915) and L. typus (EDWARDS, 1837) are species first identified in the neritic and oceanic waters off the Amazon. Samplings were made aboard the vessel "Antares" at 22 stations in July and August, 2001 with a bongo net (500- $\mu \mathrm{m}$ mesh size). Hydrological data were taken simultaneously for comparative purposes. L. faxoni was present at thirteen of the fourteen neritic stations analysed, as well as at five of the eight oceanic stations. L. typus was present at three of the fourteen neritic stations and in one of the eight oceanic stations. The highest density of L. faxoni in the neritic province was 7,000 ind. $\mathrm{m}^{-3}$ (St. 82) and 159 ind. $\mathrm{m}^{-3}$ (St. 75) in the oceanic area. For L. typus, the highest density observed was 41 ind. $\mathrm{m}^{-3}$ (St. 64) in the neritic province. In the oceanic province, the highest single density value was recorded at station $75\left(5\right.$ ind. $\left.\mathrm{m}^{-3}\right)$. Overall, L. faxoni typically presented the highest densities.
\end{abstract}

Keywords: Sergestidae; Amazon; plankton; Lucifer faxoni; Lucifer Typus.

\section{Distribuição do camarão planctônico Lucifer (Thompson, 1829) (Decapoda, Sergestoidea) na plataforma continental amazônica}

\section{Resumo}

Lucifer faxoni (BORRADAILE, 1915) e L. typus (EDWARDS, 1837) são espécies identificadas pela primeira vez nas águas neríticas e oceânicas da Amazônia. As coletas foram realizadas a bordo do navio "Antares" em 22 estações em julho e agosto de 2001, com uma rede bongô $(500 \mu \mathrm{m})$. Dados hidrológicos foram tomados simultaneamente para fins comparativos. L. faxoni esteve presente em 13 das 14 estações neríticas analisadas, bem como em 5 das 8 estações oceânicas. L. typus esteve presente em 3 das 14 estações neríticas e em 1 das 8 estações oceânicas. A maior densidade de L. faxoni na província nerítica foi de 7.000 ind. $\mathrm{m}^{-3}$ (estação 82) e 159 ind. $\mathrm{m}^{-3}$ (estação 75 ) na área oceânica. Para L. typus, a maior densidade observada foi de 41 ind. $\mathrm{m}^{-3}$ (estação 64), na província nerítica. Na província oceânica, o maior valor de densidade foi registrado na estação $75\left(5\right.$ ind. $\left.\mathrm{m}^{-3}\right)$. No geral, L. faxoni tipicamente apresentou as maiores densidades.

Palavras-chave: Sergestidae; Amazonia; plâncton; Lucifer faxoni; Lucifer typus.

\section{Introduction}

The genus Lucifer Thompson, 1829 (Luciferidae) commonly occurs in the surface layer of tropical and subtropical oceans. Members of this genus sometimes become a major component of surface-dwelling plankton (Omori, 1992). The genus consists of eight species of planktonic shrimp; however, only two species (L. faxoni Borradaile, 1915 and L. typus H. Milne Edwards, 1837) are found in the Atlantic Ocean (Omori, 1977; Lee et al., 1992). The former species is found in neritic waters, while the latter is oceanic in distribution. These species can be

easily separated by the lengths of their eyestalks, which are short in L. faxoni and long in L. typus (Bowman and McCain, 1967). L. faxoni is an important tropical neritic plankton species (Araújo et al., 2008; Almeida et al., 2012), which requires lower salinity, such as at the mouth of the Amazon River (Longhurst and Pauly, 1987). These species represent a link between primary producers and other trophic levels in the pelagic food chain (Poole and Atkins, 1929). 
In the Amazon region, information on detailed studies of zooplankton is scarce, in particular for L. faxoni and L. typus, which are commonly found in planktonic samples collected in the northern Brazilian continental shelf. Research on the species distribution off the Amazon has been performed only by Melo (2004).

This study aimed to examine the distribution of $L$. faxoni and L. typus in the Amazon continental shelf and adjacent oceanic region to further characterise the zooplankton found off the north coast of Brazil.

\section{Material and Methods}

Samples were collected at analyze22 oceanographic stations during the North IV Operation (Figure 1) performed by the oceanographic vessel "ANTARES", as part of the REVIZEE (Evaluation of Sustainable Potential of Living Resources in the Economic Exclusive Zone) programme from July $28^{\text {th }}$ to August $14^{\text {th }}, 2001$ (the transition between highest- and lowest-flow states of the Amazon River). Five profiles perpendicular to the coast $\left(04^{\circ} 30.1^{\prime} \mathrm{N}\right.$ and $00^{\circ} 05.5^{\prime} \mathrm{S}, 46^{\circ} 32.0^{\prime}$ and $48^{\circ} 52.9^{\prime} \mathrm{W}$ ) were positioned with a minimum distance of thirty miles between them. In each profile, three to six oceanographic stations were plotted and separated by 7.5 to 45 miles.

Among 22 sampling stations, 14 were located in the neritic province and eight were located in the oceanic province. Profiles were divided into the following: Profile 11 - Stations: 53, 56, 60 and 61; Profile 12 - Stations: 64, 68 and 71; Profile 13 - Stations: 72, 74, 75, 77 and 79; Profile 14 - Seasons: 82, 85, 87 and 89; and Profile 15 Stations: 90, 93, 94, 96, 97 and 98. A Bongo net (mesh size $500 \mu \mathrm{m}$ and mouth diameter of $60 \mathrm{~cm}$ ) was hauled double-obliquely at a speed of 2-2.5 knots from a depth between $14 \mathrm{~m}$ nearshore and $150 \mathrm{~m}$ in offshore waters. A flowmeter (Hydrobios, Kiel) was fitted onto the opening of the net.

Samples were preserved in a $4 \%$ buffered formalin/ seawater solution. Surface temperature, transparency, salinity and dissolved oxygen were also measured simultaneously.

In the laboratory, all L. faxoni and L. typus individuals were removed from each sample and counted under a binocular stereomicroscope, identified by sex and recorded biometric data of each. The numerical density in the water body was calculated from corresponding counts and flowmeter readings and expressed as numbers $\mathrm{m}^{-3}$ of water.

For biometric analysis were randomly selected 100 individuals $L$. faxoni were recorded and later measures eyestalk, neck, head and abdomen for each one. The total length was obtained through the sum of these segments.

\section{Results}

\subsection{Environmental characteristics}

Transparency values were generally higher in stations off the coast, reaching maximum transparency $(29 \mathrm{~m})$ at oceanic station 52 . The lowest value $(0.3 \mathrm{~m})$ was recorded at station 98, nearest the coast and under the direct influence of the Amazon plume.

Maximum water temperature $\left(28.81^{\circ} \mathrm{C}\right)$ was recorded at station 79 , and the minimum $\left(26.83^{\circ} \mathrm{C}\right)$ was recorded at station 94 with a total amplitude of $2.1^{\circ} \mathrm{C}$. In general, neritic stations showed higher temperatures with an average of $27.89^{\circ} \mathrm{C}$ (Figure 2).

The lowest salinity value (Figure 3 ) was recorded at station 56 (26.98 PSU), while the highest value was recorded in profile 15 (36.30 PSU). Profile 11 presented the lowest average salinity value in the study area (30.09 PSU).

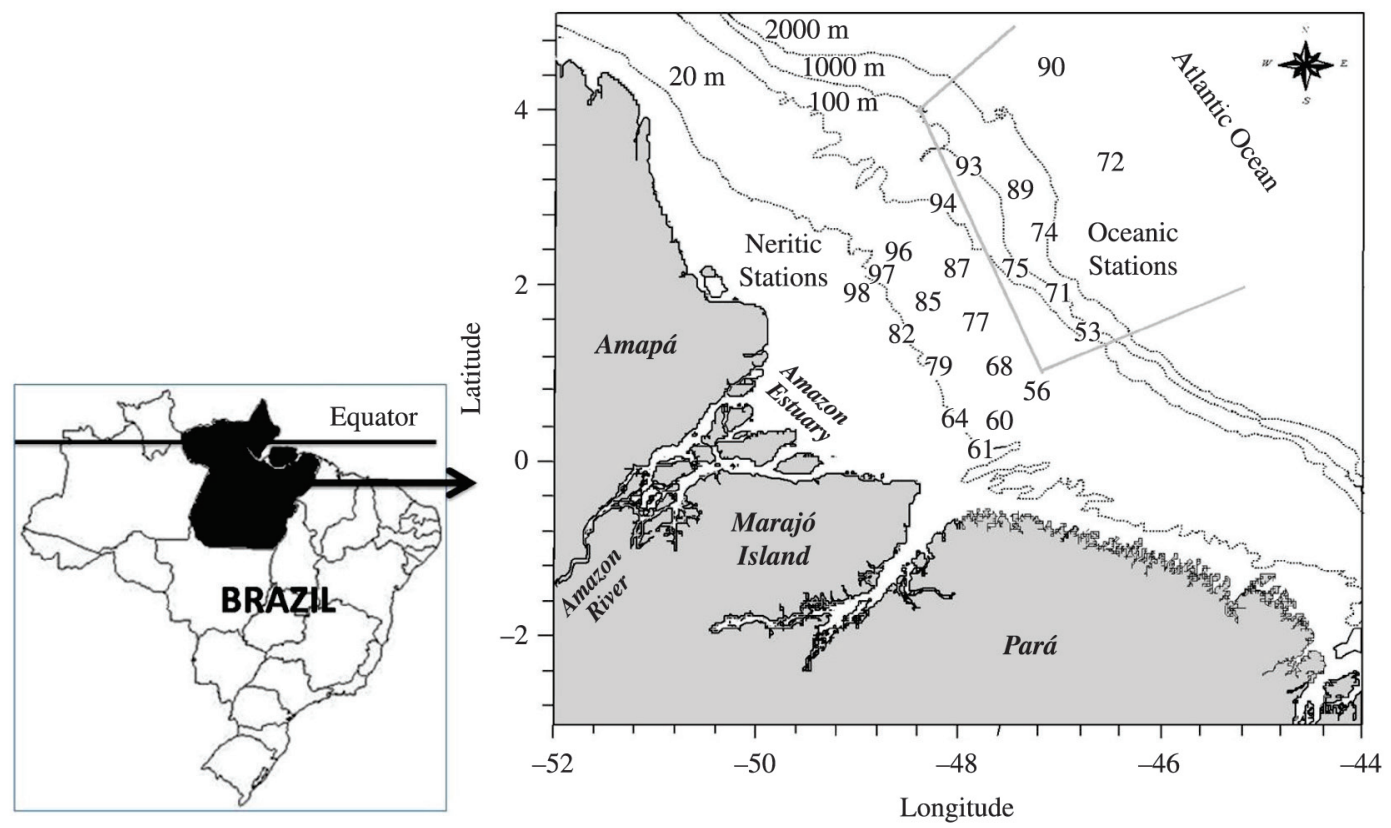

Figure 1. North Brazilian coast map depicting the sampling stations. 
The lowest surface dissolved oxygen value was recorded at station $60\left(4.41 \mathrm{ml} . \mathrm{L}^{-1}\right)$, while the highest value $(7.68$ $\mathrm{mL} . \mathrm{L}^{-1}$ ) was recorded at station 56 , profile 11 , with a total amplitude of 3.27 mL.L - $^{-1}$ (Figure 4). Profile 14 presented the lowest average salinity values $\left(4.87 \mathrm{ml} . \mathrm{L}^{-1}\right)$ among all studied areas.

\subsection{Variations in Lucifer abundance}

L. faxoni was present in 13 of the 14 neritic stations analysed, with a $92.9 \%$ frequency of occurrence. For stations located in the oceanic province, the species was present in six (6) of the eight (8) stations analysed and the frequency value was $75.0 \%$.

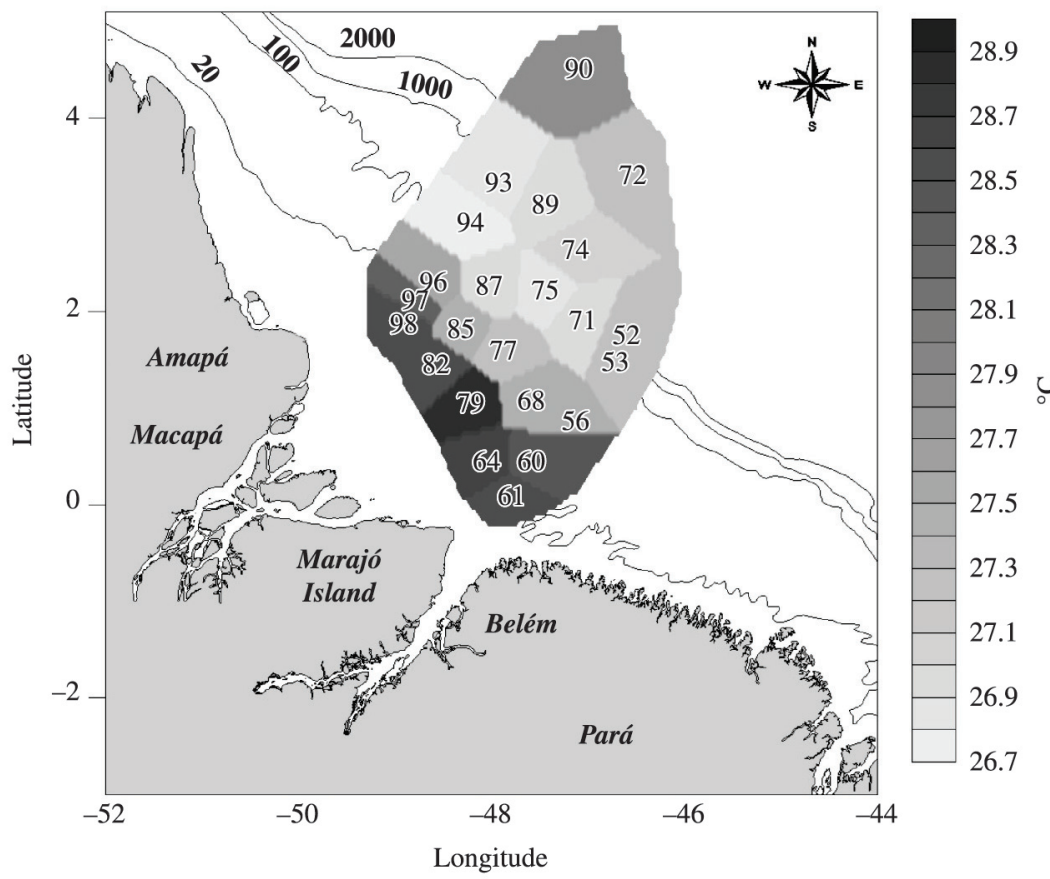

Figure 2. Variation of surface temperature $\left({ }^{\circ} \mathrm{C}\right)$ in neritic and oceanic provinces of Amapá and Pará states during the Norte IV Operation, REVIZEE programme.

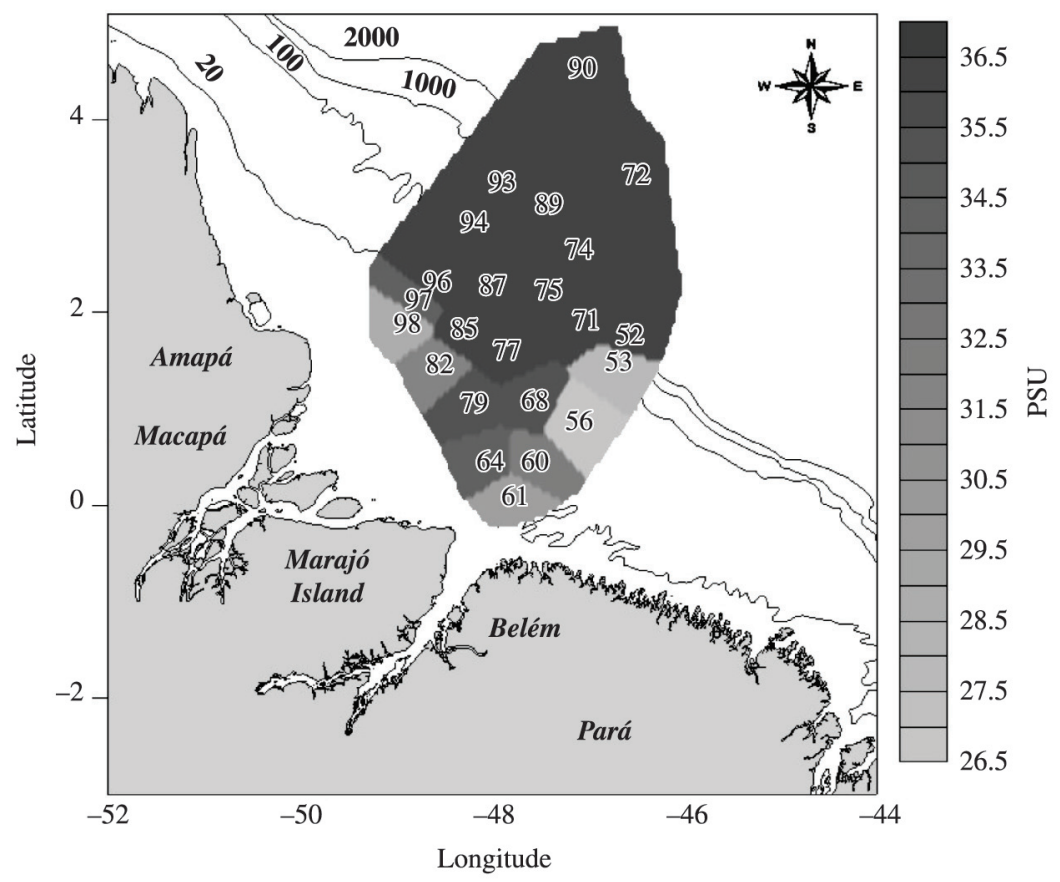

Figure 3. Variation of salinity (PSU) in neritic and oceanic provinces of Amapá and Pará states during the Norte IV Operation, REVIZEE programme. 
L. typus was present at three (3) of the fourteen (14) neritic stations $(21.4 \%)$ and one (1) of the eight (8) oceanic stations (12.5\%) analysed.

Considering the study area as a whole, L. faxoni was present in eighteen (18) of the twenty-two (22) stations analysed (81.1\%). L. typus occurred in only four (4) out of twenty-two (22) stations (18.2\%).

When compared to the oceanic province, the neritic province showed higher abundance values for $L$. faxoni and L. typus, in terms of the total number of individuals found in the samples. It is important to emphasise that L. faxoni presented higher abundance than L. typus. The maximum abundance of $L$. faxoni was recorded at station $82(90.00 \%)$, while L. typus presented its highest relative abundance at station $77(1.06 \%)$ (Figure 5). For the oceanic province, the highest values for $L$. faxoni and L. typus were recorded at stations 53 (6.94\%) and 75 $(0.21 \%)$, respectively.

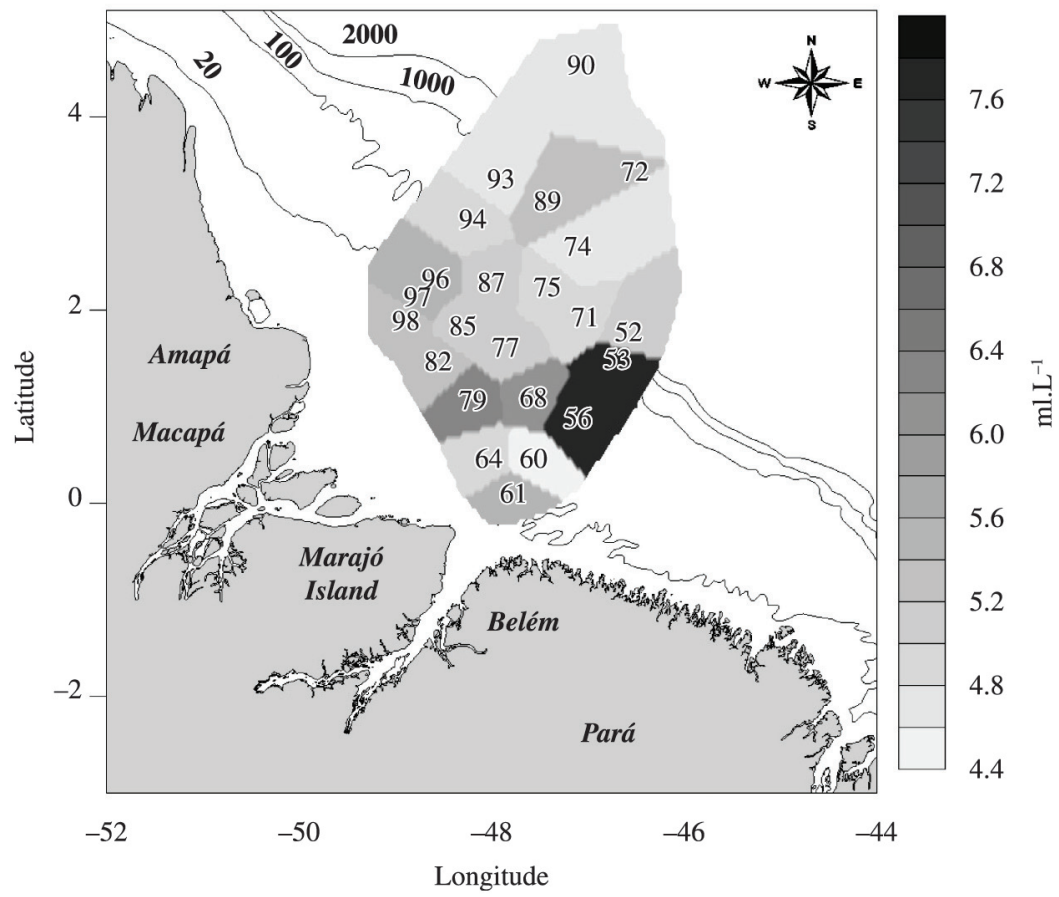

Figure 4. Variation of dissolved oxygen $\left(\mathrm{ml} \cdot \mathrm{L}^{-1}\right)$ in neritic and oceanic provinces of Amapá and Pará states during the Norte IV Operation, REVIZEE programmeme.

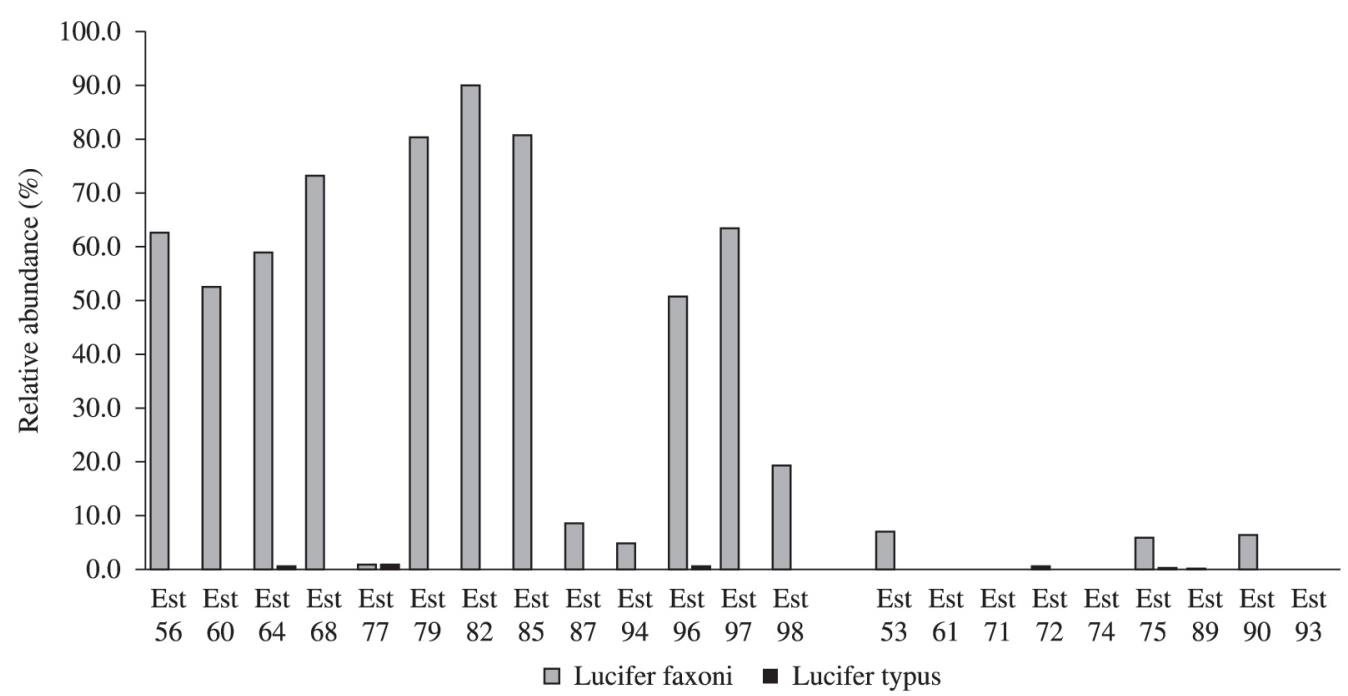

Figure 5. Relative abundance of L. faxoni and L. typus at sampling stations in the neritic and oceanic provinces of Amapá and Pará States during the North IV Operation, REVIZEE programme. 
Density values at stations where $L$. faxoni larvae (Figure 6) were observed were higher than those presented by L. typus (Figure 7). At neritic stations, the highest value for L. faxoni occurred at station 82 (7000 ind. $\left.\mathrm{m}^{-3}\right)$, while for L. typus, the highest density value (41 ind. $\mathrm{m}^{-3}$ ) was observed at station 64 . The lowest values for both species (9 ind. $\mathrm{m}^{-3}$ ) were recorded at station 77 for L. faxoni and station 96 for L. typus.

Among the individuals selected for biometric analysis, 56 females and 44 males were found. After verification of the measurements in total length, mean, standard deviation, and coefficient of variation were calculated, land recorded the maximum and minimum for each sex (Table 1).

\section{Discussion}

The zooplankton population in neritic and oceanic areas, comprising primarily Decapoda shrimp, is usually affected by many physico-chemical processes. In the present study, the Amazon Shelf, due to the influences of both Para and Amazon rivers, is an unusually energetic coastal region that is subjected to strong seasonally driven forces, such as the Amazon River discharge, North Brazil Current transport, and trade-winds. Due to its proximity to the Equator, moderate along-shelf geostrophic currents may be generated by weak cross-shelf pressure gradients in the area's northern and southern regions (Silva et al., 2005). The formation and characteristics (depth and thickness) of the barrier and mixed layer vary seasonally, and a barrier layer (BL) is formed in distinct areas by different processes. Along the shelf break, the formation of the $B L$ seems also to be associated with the advection of the subsurface maximum salinity waters, formed in the region of the subtropical gyres and transported to the study area by the NBC/NBUC system (Stramma et al., 1995, 2005; Pailler et al., 1999).

These processes were important in structuring the presence of the Lucifer genus in the region. In general, L. faxoni and L. typus presented higher abundance at stations near the coast, in lower depths and mainly at night (between 20:00 and 4:00 h). In addition to the adults' diel vertical migration (Checkley Junior et al., 1992), there is also diel spawning activity, with eggs being spawned during the evening or at night. This behavior is common to many marine organisms and serves to reduce predation by planktivores (Lee et al., 1992).

Lucifer faxoni presented higher distribution and density in the studied area. According to Longhurst and Pauly (1987), L. faxoni is an important species among tropical neritic plankton that require lower salinity, such as in the mouth of the Amazon River. This river reaches an average of $1.810^{5} \mathrm{~m}^{3} \mathrm{~s}^{-1}$ of freshwater (Figueiredo et al., 1991), representing $18 \%$ of the total freshwater of all rivers that are discharged into the ocean (Milliman and Meade, 1983; Kineke et al., 1996, Smith Junior and Demaster, 1996). The second largest river in the draining system of the Amazon is the Pará River, which presents an estimated discharge of $10^{4} \mathrm{~m}^{3} \mathrm{~s}^{-1}$ (Oltman, 1968), due to seasonal rainfall in the Amazon region. Both drainage systems are responsible for the change in salinity and other physicochemical properties in the Amazon River plume, which

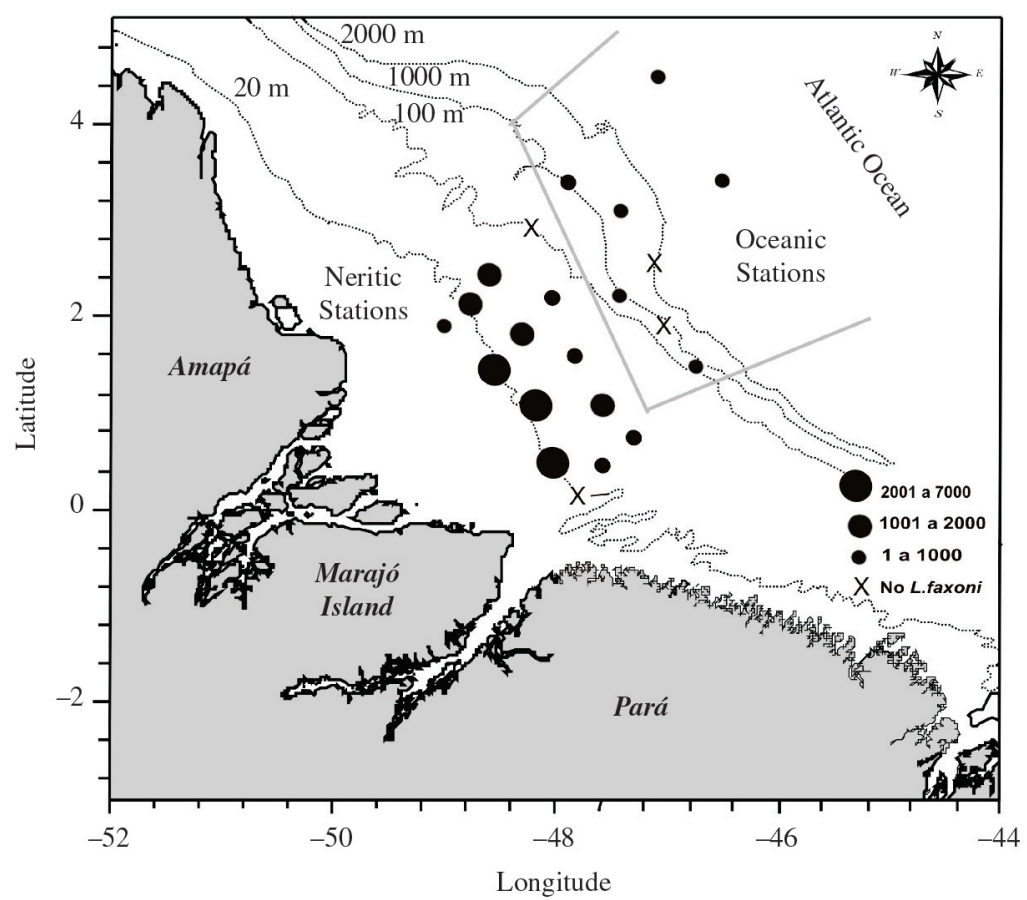

Figure 6. Density variation of $L$. faxoni at sampling stations during the North IV Operation, REVIZEE programme. 


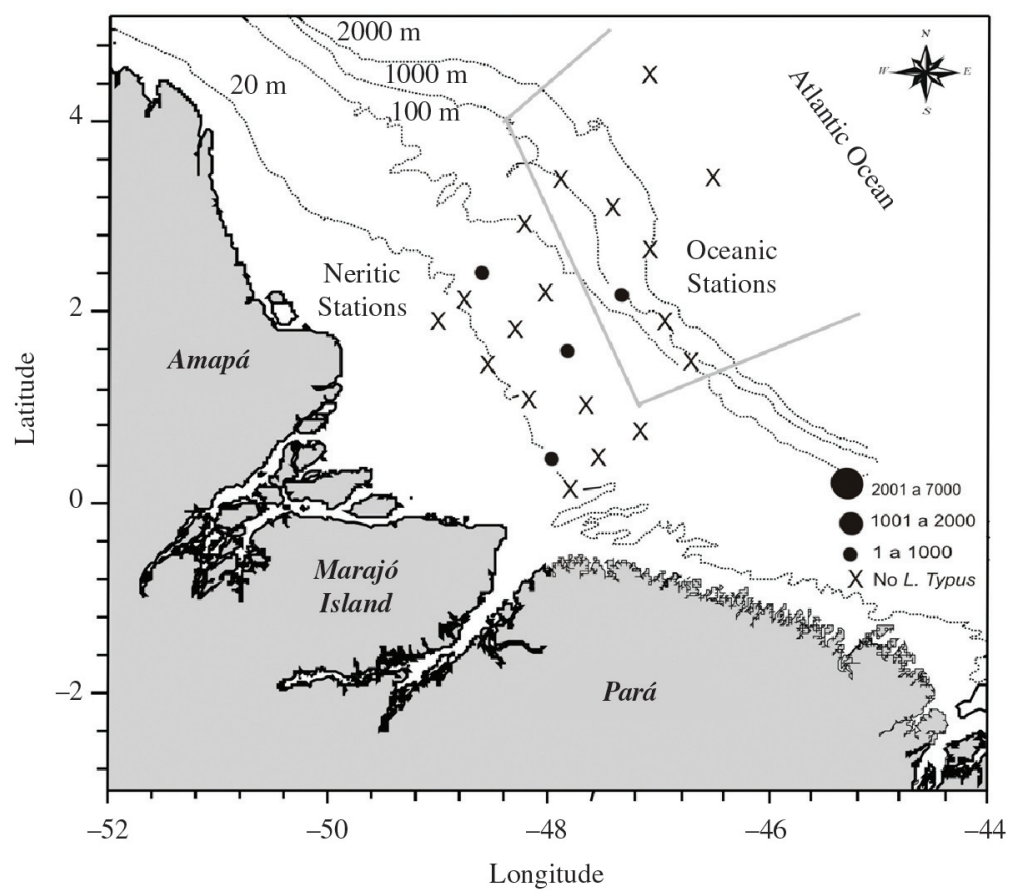

Figure 7. Density variation of L. typus at sampling stations during the North IV Operation, REVIZEE programme.

Table 1. Measures in total length were calculated for mean, standard deviation, coefficient of variation and the maximum and minimum recorded for each sex.

\begin{tabular}{lccccc}
\hline & Average & $\begin{array}{c}\text { Standard } \\
\text { Desviation }\end{array}$ & $\begin{array}{c}\text { Coefficient of } \\
\text { Variation }\end{array}$ & Minimum & Maximum \\
\hline Female & 6.9 & 1.8 & 26.1 & 2.1 & 11.6 \\
Male & 7.4 & 0.6 & 8.0 & 5.8 & 8.9 \\
\hline
\end{tabular}

may significantly influence the distribution and abundance of various groups of organisms in this area.

L. typus did not show high densities in either the neritic or oceanic provinces, with a slightly higher abundance at the first. L. typus is essentially oceanic and one of the few species of the genus Lucifer, with circumglobal distribution in warm waters. Because it is abundant, easy to identify, and limited to oceanic water, Lucifer typus is a potentially useful indicator species (Bowman and McCain, 1967). Longhurst and Pauly (1987) report that this species is more abundant in high-salinity oceanic areas, however, this distribution pattern was not observed during the present study.

The low values of standard deviation measures the total length of males and female show homogeneity between themselves and the population of $L$. faxoni as a whole. On the other hand the difference in the values of coefficient of variation proves that the female population had a higher variation of total length.

Knowledge of zooplankton is of great importance, especially in modeling trophodynamics, which constitute an important link in the transfer of energy and in several complex processes controlling matter flux (Longhurst and Pauly, 1987). Moreover, most of the samples in this study come from the pelagic area above the shelf break; according to Hopkins et al. (1981) and Angel (1996), there is a sudden change in the pelagic community along the shelf break of continental margins, related to the reduction in density and increase in biodiversity towards neritic-ocean.

In our study, it appears that the plume of the Amazon establishes extreme variability in the hydrographic conditions of the continental shelf and the adjacent area, which in turn creates a complex mosaic of habitats for zooplankton development, including that of L. faxoni and L. typus. In general, L. faxoni and L. typus were abundant in most neritic samples. L. faxoni plays a key role among the tropical neritic plankton that require lower salinity, such as those found in the mouth of the Amazon River.

\section{Acknowledgments}

We are thankful to the MMA (Ministry of Environment, Water Resources and the Amazon) and CIRM (Interministerial Commission for Sea Resources) for financial support for the REVIZEE program. We are thankful to the American Journals Experts for the review this paper. 


\section{References}

ANGEL, MV., 1996. Biodiversity of Pelagic Ocean. In PIRIE, EG. (Ed.). Oceanography: contemporary readings in Ocean Sciences. Oxford: Oxford University Press. p. 192-206.

ALMEIDA, LR., COSTA, IS. and ESKINAZI-SANT'ANNA, EM., 2012. Composition and abundance of zooplankton community of an impacted estuarine lagoon in Northeast Brazil. Revista Brasileira de Biologia = Brazilian Journal of Biology, vol. 72, no. 1, p. 12-24. http://dx.doi.org/10.1590/S1519-69842012000100002. PMid:22437380

ARAÚJO, HM., NASCIMENTO-VIEIRA, DA., NEUMANNLEITÃO, S., SCHWAMBORN, R., LUCAS, AP. and ALVES, JP., 2008. Zooplankton community dynamics in relation to the seasonal cycle and nutrient inputs in an urban tropical estuary in Brazil. Revista Brasileira de Biologia = Brazilian Journal of Biology, vol. 68, no. 4, p. 751-762. http://dx.doi.org/10.1590/ S1519-69842008000400009. PMid:19197492

BOWMAN, TE. and MCCAIN, JC., 1967. Distribution of the planktonic shrimp, Lucifer, in the western North Atlantic. Bulletin of Marine Science, vol. 17, p. 660-671.

CHECKLEY JUNIOR, DM., UYE, S., DAGG, M., MULLIN, G., OMORI, M., ONBÉ, M. and ZHU, M-Y., 1992. Diel variation of the zooplankton and its environment at neritic stations in the Inland Sea of Japan and the North-west Gulf of Mexico. Journal of Plankton Research, vol. 14, no. 1, p. 1-40. http://dx.doi. org/10.1093/plankt/14.1.1.

FIGUEIREDO, AG., ALISSON, M. and NITROUER, CA., 1991. Amazon discharge: internal report for AMASSEDS researchers. Niterói: Universidade Federal Fluminense. (Technical Report).

HOPKINS, TL., MILLIKEN, DM., BELL, LM., MCMICHAEL, EJ., HEFFERNAN, JJ. and CANO, RV., 1981. The landward distribution of oceanic plankton and micronekton over the west Florida continental shelf as related to their vertical distribution. Journal of Plankton Research, vol. 3, no. 4, p. 645-658. http:// dx.doi.org/10.1093/plankt/3.4.645.

KINEKE, GC., STERNBERG, RW., TROWBRIDGE, JH. and GEYER, WR., 1996. Fluid-mud processes on the Amazon continental shelf. Continental Shelf Research, vol. 16, no. 5-6, p. 667-696. http://dx.doi.org/10.1016/0278-4343(95)00050-X.

LEE, W., OMORI, Y. and PECK, R., 1992. Growth, reproduction and feeding behavior of the planktonic shrimp, Lucifer faxoni Borraidele, off the Texas coast. Journal of Plankton Research, vol. 14, no. 1, p. 61-69. http://dx.doi.org/10.1093/plankt/14.1.61.

LONGHURST, AR. and PAULY, D., 1987. (Eds.). Ecology of tropical oceans. San Diego: Academic Press. 407 p.
MELO, NFAC., 2004. Biodiversidade e Biomassa do Macrozooplâncton, com Ênfase nos Copépoda (Crustacea) na Plataforma Continental Norte Brasileira. Recife: Universidade Federal Pernambuco. 101 p. Tese de Doutorado em Oceanografia.

MILLIMAN, J. and MEADE, R., 1983. World-wide delivery of river sediment to the oceans. The Journal of Geology, vol. 91, no. 1, p. 1-21. http://dx.doi.org/10.1086/628741.

OLTMAN, RE., 1968. Reconnaissance investigations of the discharge and water quality of Amazon river. Washington: United States Department of the Interior. 16 p. (Geological Survey Circular, no. 522).

OMORI, M., 1977. Distribution of warm water epiplanktonic shrimps of the genera Lucifer and Acetes (Macrura, Penaeidae, Sergestidae). In Proceedings of the Symposium on Warm Water Zooplankton. Goa, India: National Institute of Oceanography. (Special publication of UNESCO/NIO). p. 1-12.

OMORI, M., 1992. Occurrence of two species of Lucifer (Dendrobranchiata: Sergestoidea: Luciferidae) off the Pacific coast of America. Journal of Crustacean Biology, vol. 12, no. 1, p. 104-110. http://dx.doi.org/10.2307/1548725.

PAILLER, K., BOURLÈS, B. and GOURIOU, Y., 1999. The barrier layer in the western tropical Atlantic Ocean. Geophysical Research Letters, vol. 26, no. 14, p. 2069-2072. http://dx.doi. org/10.1029/1999GL900492.

POOLE, HH. and ATKINS, WRG., 1929. Photo-eletric measurements of submarine illumination throughout the year. Journal of the Marine Biological Association of the United Kingdom, vol. 16, no. 1, p. 297-324. http://dx.doi.org/10.1017/S0025315400029829.

SILVA, AC., ARAUJO, M., MEDEIROS, C., SILVA, MA. and BOURLES, B., 2005. Seasonal changes in the mixed and barrier layers in the Western Equatorial Atlantic. Brazilian Journal of Oceanography, vol. 53, no. 3-4, p. 1-16.

SMITH JUNIOR, WO. and DEMASTER, D., 1996. Phytoplankton biomass and productivy in the Amazon River plume: correlation with seasonal river discharge. Continental Shelf Research, vol. 16, no. 3, p. 291-319. http://dx.doi.org/10.1016/0278-4343(95)00007-N.

STRAMMA, L., FISCHER, J. and REPPIN, J., 1995. The North Brazil Undercurrent. Deep-sea Research. Part I, Oceanographic Research Papers, vol. 42, no. 5, p. 773-795. http://dx.doi. org/10.1016/0967-0637(95)00014-W.

STRAMMA, L., RHEIN, M., BRANDT, P., DENGLER, M., BONING, C. and WALTER, M., 2005. Upper ocean circulation in the western tropical Atlantic in boreal fall 2000. Deep-sea Research. Part I, Oceanographic Research Papers, vol. 52, no. 2, p. 221-240. http://dx.doi.org/10.1016/j.dsr.2004.07.021. 